\title{
PENTINGNYA PENDIDIKAN INTERRELIGIUSITAS DI SEKOLAH DASAR
}

\author{
Paulus Dwi Hardianto
}

\begin{abstract}
:
In Indonesia, the last twenty years many cases had happened that caused disharmony. Some radical groups attacked different communities due to their different point of view. According to PPIM's research, not few teachers in Java have taught intolerance to their students. In this context, using a descriptive research with both qualitative and quantitative approaches (observation, questionnaire, and interview), the writer undertook a scientific research in some main Catholic's schools in Jakarta e.g. Strada, Van Lith I Elementary School, Tarakanita V Elementary School, Melania II Elementary School and Budi Mulia Elementary School which have been trying to teach tolerance and pluralism to students. These Catholic schools had made a serious effort to incorporate the subject of tolerance and pluralism into their curriculum especially based on the thought of Jean Piaget, Lawrence Kohlberg, James W. Fowler as well as Gravissimum Educationis. From the result of this research, the writer is convinced of their contribution to peaceful coexistence in the country. Learning from them, the writer proposes again the importance of interreligious education in our pluralistic society.
\end{abstract}

\section{Kata-Kata Kunci:}

Sekolah Dasar Katolik, pendidikan, toleransi, pluralisme, keterbukaan, interreligiusitas.

\section{PENDAHULUAN}

\subsection{Latar Belakang Masalah}

Pada tahun 2012, Setara Institut pernah menyatakan bahwa masyarakat Jabodetabek adalah masyarakat yang intoleran. Tindakan intoleransi mewujud dalam bentuk intimidasi dan ancaman kekerasan yang mengatasnamakan agama, pernyataan dan penyebaran kebencian terhadap kelompok lain, pembakaran dan perusakan properti serta diskriminasi atas dasar agama atau keyakinan. ${ }^{1}$ Menurut Setara Institut pula, eskalasi kekerasan berbasis agama dalam bentuk penyerangan rumah ibadah, khususnya terhadap jemaat Kristiani, terus meningkat. Pada 2008, paling sedikit terdapat sekitar 17 kasus dan meningkat menjadi 18 kasus pada 2009. Pada 2010, tercatat sebanyak 28 kasus pelanggaran kebebasan dan berkeyakinan. Pelanggaran terjadi mulai dari penolakan pendirian rumah ibadah, penyegelan, pembakaran, dan penghentian paksa kegiatan ibadah. ${ }^{2}$

Pada tahun-tahun yang kurang lebih sama, Pusat Pengkajian Islam dan Masyarkat (PPIM) Universitas Islam Negeri Syarif Hidayatullah Jakarta, mengadakan survey bagi 500 guru agama di sekolah-sekolah publik maupun privat di Jawa. Survey menunjukkan bahwa sebagian besar guru menolak pluralisme dan cenderung mengarah pada 
radikalisme dan konservatisme. Sebanyak 68,6\% guru menolak orang non Muslim menjadi kepala sekolah mereka dan 33,8\% menolak adanya rekan non Muslim yang menjadi guru di sekolah mereka. Sebanyak 86,5\% responden melarang para muridnya untuk merayakan even-even besar yang dipandang sebagai produk budaya Barat dan 87\% guru mengajarkan murid agar tidak mempelajari agama lain. ${ }^{3}$

Adanya tindakan intoleran dan kecenderungan perkembangan radikalisme dan konservatisme inilah yang menjadi keprihatinan penulis. Keprihatinan ini juga menjadi salah satu fokus yang penting dalam Arah Dasar Keuskupan Agung Jakarta (Ardas KAJ) 2011-2015. Penulis berupaya melibatkan diri dalam pengentasan intoleransi dengan mencari cara bagaimana toleransi itu dapat ditumbuhkembangkan, yakni melalui pendidikan di sekolah.

\subsection{Rumusan Masalah}

Pendidikan toleransi dan pluralisme merupakan proses yang terus menerus dipelajari oleh manusia. Proses itu dijalani sedari kecil dengan tahap-tahap tertentu seiring dengan perkembangan fisik dan budi manusia. Selain perkembangan fisik, pengaruh lingkungan sekitar turut mempengaruhi proses berpikir dan bertindak seseorang tersebut. Tahap-tahap perkembangan kognitif pada manusia itu diteliti oleh Jean Piaget. Dengan bantuan penelitian Piaget, kita dapat mengetahui kapan manusia secara sadar dapat berinteraksi dengan manusia lain sehingga manusia dapat mengambil sikap terhadap orang lain. Dalam hal ini, Piaget menunjukkan bahwa ada empat tahap perkembangan kognitif yang memiliki karakteristik masing-masing.

Lawrence Kohlberg dan James Fowler terinspirasi oleh hasil penelitian Piaget ini. Pengandaiannya adalah, jika ada tahap-tahap perkembangan kognitif maka dimungkinkan pula ada tahaptahap perkembangan moral dan perkembangan iman. Kohlberg meneliti tahap-tahap perkembangan moral, sedangkan Fowler meneliti tahap-tahap perkembangan iman. Menurut Kohlberg, ada tiga tiga tahap perkembangan moral dan pada masingmasing tahap terdapat dua sub-tahap. Sedangan menurut Fowler, ada enam tahap perkembangan iman dan semua tahap tersebut memiliki karakteristik masing-masing.

Dalam rangka pendidikan toleransi dan pluralisme, ketiga teori tersebut akan dapat membantu kita dalam menjelaskan beberapa pertanyaan dasar. Pertama, kapan dan bagaimana manusia dapat memahami dunia luar yang plural? Kedua, kapan dan bagaimana manusia dapat berkembang secara moral dengan terbuka pada yang lain? Ketiga, kapan dan bagaimana pendasaran iman dapat dicapai dan dikembangkan oleh manusia? Perkembangan iman yang dituju adalah iman yang tetap terbuka pada perbedaan iman orang lain.

Dalam tahap-tahap perkembangan kognitif menurut Piaget, kita dapat mengetahui bagaimana kemampuan kognitif manusia dalam usia-usia tertentu dapat memahami dan menerima pengetahuan beserta kompleksitasnya yang berkaitan dengan dunia sosial kemasyarakatan. Kemudian, di setiap tahap-tahap perkembangan, ada tahap paling akhir yang menjadi nilai paling ideal yang perlu dicapai oleh semua orang. Kohlberg mengusulkan tahap Orientasi Azas Etika Universal sebagai puncak kedewasaan moral. Sedangkan Fowler memiliki tahap Iman Universal sebagai puncak kedewasaan iman. Kesamaan karakteristik kedua tahap itu adalah adanya keterbukaan pada perbedaan yang ada. Ketiga tokoh tersebut menekankan bahwa setiap orang harus atau akan melewati setiap tahap, satu demi satu. Tidak ada orang yang langsung melompat dari tahap satu ke tahap empat dan seterusnya.

\subsection{Tujuan Penulisan}

Penulis telah meneliti sekolah-sekolah dasar Katolik di Jakarta (SD Strada Van Lith I, SD Tarakanita V, SD Melania II, dan SD Budi Mulia) untuk melihat bagaimana kepada para peserta didik diajarkan toleransi dan pluralisme. Ada empat hal yang menjadi fokus penelitian penulis. Pertama, penulis ingin menelusuri bagaimana peran sekolah dasar Katolik dalam mendidik siswa-siswi di Jakarta menjadi pribadi-pribadi yang terbuka dan toleran. Periode umur anak di sekolah dasar dipilih karena pada masa inilah anak-anak dapat berkembang secara kognitif dan mulai terbuka pada dunia luar. Ini sesuai dengan kerangka teori Piaget. Kedua, melalui penelitian buku-buku pelajaran agama dan Pendidikan Kewarganegaraan (PKn) di beberapa sekolah dasar Katolik di Jakarta, penulis ingin mengetahui bagaimana peran dunia pendidikan, khususnya pendidikan agama dan PKn berpartisipasi dalam mengentaskan intoleransi. Ketiga, penulis ingin mengetahui situasi apakah siswa-siswi sekolah dasar Katolik itu terbuka atau toleran terhadap orang yang berbeda agama atau suku. Dan, keempat, penulis ingin mengetahui bagaimana semuanya itu tercermin dalam buku-buku pelajaran agama dan PKn, wawancara dengan para murid, guru dan orangtua. 


\subsection{Metode Penulisan}

Penulis menggunakan metode deskriptif meliputi penelitian kualitatif dan kuantitatif (observasi, kuesioner, dan wawancara) di sekolah katolik. Dalam penelitian yang telah dibuat, penulis mengembangkan analisa dan sintesa dalam perspektif ilmu psikologi dan teologi moral. Penulis dibantu oleh pemikiran Jean Piaget, Lawrence Kohlberg, dan James W. Fowler dengan teori tahap-tahap 'Perkembangan Kognitif', 'Perkembangan Moral', dan 'Perkembangan Iman', serta Dokumen Konsili Vatikan II tentang pendidikan, yaitu Deklarasi "Gravissimum Educationis” (selanjutnya: GE). Akan tetapi karena makalah ini hanya menekankan aspek pentingnya pendidikan toleransi dan pluralisme dari segi teori Piaget, Kohlberg dan Fowler, maka penjelasan dari sudut pandang "Gravissimum Educationis” hanya dijabarkan sekilas.

\section{REFLEKSI DALAM KERANGKA TEORI J. PIAGET, L. KOHLBERG, DAN J. W. FOWLER}

\subsection{Kerangka Pikir Tahap Perkembangan Kognitif Jean Piaget dalam Data Penelitian}

Menurut Piaget, sejak lahir sampai mencapai kedewasaan, proses berpikir berubah secara radikal meskipun berjalan dengan lamban, karena manusia berusaha memahami dunia secara konstan. Ada empat faktor yang berpengaruh dalam proses berpikir tersebut bagi Piaget, yaitu kematangan biologis, aktivitas, pengalaman sosial dan ekuilibrasi. ${ }^{4}$

Bagi Piaget, ekuilibrium atau keseimbangan dalam hidup akan terus dicari manusia. Setiap skema baru yang dijumpai dalam pengalaman manusia akan dihadapkan pada skema-skema yang sudah ada. Apabila skema itu cocok, maka ekuilibrium terjadi. Sebaliknya ketika skema yang sudah ada tidak cocok atau tidak membuahkan hasil yang memuaskan, terjadilah disekuilibrium atau ketidakseimbangan. Solusi yang ditempuh manusia adalah beradaptasi dengan cara asimilasi dan akomodasi, sehingga manusia dapat mengubah pikiran dan pandangannya untuk mencapai keseimbangan hidup.

Dengan berbekal pandangan Piaget, maka setiap tahapan perkembangan kognitif yang dipetakannya dalam empat tahap tetap, sangat dipengaruhi oleh empat faktor yaitu kematangan biologis, aktivitas, pengalaman sosial dan ekuilibrasi.

\subsubsection{Masa Sekolah Dasar: Tahap Perkembangan Operasional Konkret}

Piaget melihat secara garis besar bahwa anakanak yang berada pada umur 7 sampai dengan 12 tahun (usia ini merupakan usia anak SD di Indonesia pada umumnya) berada dalam Tahap Operasional Konkret. Kata 'operasional konkret' digunakan untuk mendeskripsikan tahap berpikir 'hands on' dalam arti konkret; melibatkan sentuhan fisik secara langsung. ${ }^{5}$ Pada tahap ini, perkembangan anak ditandai dengan penggunaan logika yang memadai. ${ }^{6}$

Pada usia ini anak memiliki kemampuan untuk mengklasifikasi sesuatu berdasarkan karakteristik tertentu. Ia dapat mengklasifikasi sekelompok objek, misalkan kelereng berdasarkan warna, dan ukurannya. Dengan demikian, ia pun dapat membedakan teman-temannya berdasarkan warna kulit, tinggi, bentuk rambut, sampai suku atau agama temannya. Proses-proses penting selama tahapan ini adalah mengenal bentuk, ukuran, ciriciri dan lain sebagainya. Selain itu, anak-anak dapat memahami hukum-hukum percakapan dan mampu mengklasifikasikan dan mengurutkan sesuatu dari besar ke kecil dan juga sebaliknya. ${ }^{7}$ Dengan demikian, anak mengenal suatu 'keberagaman' secara sederhana seperti beragamnya jenis kelereng berdasarkan klasifikasi yang dibuatnya.

Dalam data secara umum dari kelas 1 sampai dengan kelas 6, anak dapat mengklasifikasi agama -agama dan suku-suku yang ada di Indonesia. Mereka dapat membedakan agama satu dengan agama yang lain serta dapat membedakan suku yang satu dengan suku yang lain. Mereka dapat menyebutkan adanya enam agama di Indonesia yaitu Katolik, Kristen, Islam, Hindu, Buddha dan Konghucu. Mereka pun dapat menyebutkan dan membedakan banyaknya suku-suku di Indonesia. Mereka dapat menunjukkan identitas teman-teman dengan agama atau suku yang melekat pada diri teman mereka.

Selanjutnya, menurut Piaget, ketika mulai berhadapan dengan keberagaman yang sudah dapat dipahami, anak mulai belajar untuk menghilangkan sifat egosenstrismenya. Yang berperan dalam proses ini adalah unsur adaptasi yang berupa asimilasi dan akomodasi. Ada penghilangan sifat egosentrisme yaitu kemampuan untuk melihat suatu masalah dari sudut pandang orang lain. Di sini terjadi proses 'decentering', yaitu masa di mana anak mulai mempertimbangkan beberapa aspek dari suatu permasalahan 
dengan berbagai pertimbangan agar dapat memecahkannya.

Dalam masa Tahap Operasional Konkret ini, anak mampu untuk bersikap kooperatif karena pendapatnya dapat berbenturan dengan pandangan orang lain. Dalam proses adaptasinya, anak dapat meninggalkan pandangannya sendiri yang berbeda dari yang lain dan menyelaraskan pandanganpandangan yang berbeda tersebut. Diskusi yang sesungguhnya dapat terjadi pada masa ini, di mana anak dapat memahami dengan respek terhadap pandangan orang lain dan mencari kebenaran atau bukti terhadap pernyataan mereka masingmasing. ${ }^{8}$

Dalam data penelitian penulis, tampak bahwa para siswa-siswi mulai memikirkan kepentingan bersama, bukan dirinya sendiri lagi. Siswa-siswi mulai belajar untuk memperhatikan kepentingan bersama. ${ }^{9}$ Semua responden mengetahui bahwa setiap orang harus menghargai, menghormati dan hidup bersama dengan orang lain yang berbeda. Sebagian besar responden tersebut pun dapat dikatakan cukup memahami mengapa setiap orang harus menghargai, menghormati dan hidup berdampingan dengan orang lain yang berbeda.

\subsubsection{Realitas Pendidikan Toleransi dan Plura- lisme dalam Kerangka Pikir Jean Piaget}

Berdasarkan teori Piaget, penulis menangkap bahwa peran guru di sekolah adalah mengarahkan dan memfasilitasi proses adaptasi yang berupa asimilasi dan akomodasi. Fokus dalam mengarahkan dan memfasilitasi tersebut berdasarkan karakteristik tingkat kognitif anak yaitu pada Tahap Operasional Konkret yang berciri sudah dapat mengklasifikasi, cenderung berpikir 'decentering' atau mulai menghilangkan sifat egosentrismenya. Agar dapat berkembang secara konkret, anak diberikan aktivitas dan pengalaman sosial yang merupakan bagian dari proses yang mempengaruhi proses berpikir anak.

\subsubsection{Pembelajaran Klasifikasi}

Ibu Astuti, guru agama SD Strada Van Lith I, mengajarkan para muridnya untuk menghargai dan menghormati orang lain yang berbeda. Ia menggunakan contoh-contoh, cerita-cerita dan maket-maket yang diharapkan dapat mempermudah anak untuk memahami pentingnya hidup dalam keberagaman. SD Strada Van Lith I memiliki maket-maket yang berupa gambar orang dari suku tertentu dan gambar orang dari agama tertentu dengan rumah ibadah masing-masing. Hal yang sama juga terjadi di SD Budi Mulia.
Di SD Tarakanita V, siswa-siswi mendapat pelajaran Pendidikan Religiusitas. Pendidikan Religiusitas memiliki tiga tujuan utama. Pertama, siswa yang beragama Katolik semakin mampu memahami dan menghayati iman Katolik, tetapi juga terbuka terhadap kesaksian iman siswa yang beragama lain. Kedua, siswa yang beragama lain semakin menghayati agamanya sendiri, tetapi juga terbuka terhadap kesaksian iman siswa yang beragama Katolik. Ketiga, siswa yang beragama Katolik dan yang beragama lain semakin dapat membangun dan memperkembangkan kebersamaan hidup yang membawa damai dan membahagiakan. ${ }^{10}$

\subsubsection{Pembelajaran Menghilangkan Sifat Egoisme}

Perkumpulan Strada memiliki salah satu misi yaitu "Peduli terhadap sesama, menghargai keberagaman, dan berjuang demi terpeliharanya lingkungan hidup.” Sesuai dengan misi yayasan, SD Strada Van Lith I juga memiliki tujuan yang sama untuk peduli terhadap sesama, menghargai keberagaman, dan berjuang demi terpeliharanya lingkungan hidup. Semangat inilah yang dibawa dalam menjalankan proses belajar mengajar di sekolah ini.

Bapak Harisantosa, guru agama, mengatakan bahwa SD Tarakanita V memiliki program khusus dalam mengembangkan segi humanis siswa-siswi yaitu dengan pendidikan karakter (PKT) (Lamp. 43). Dalam pendidikan karakter, siswa diajarkan tentang nilai-nilai dalam Cc 5 (Cc 5 adalah pedoman-pedoman nilai hidup yang diajarkan di Sekolah Tarakanita.) termasuk di antaranya adalah keterbukaan pada perbedaan. Bapak Harisantosa sering mengajak siswa-siswi kelas 5 dan 6 untuk berdiskusi dalam kelompok dalam rangka mengembangkan sikap toleran yang juga merupakan pengejawantahan dari salah satu misi Yayasan Tarakanita.

Bapak Agustian, guru agama SD Melania, mengajarkan anak didiknya untuk saling menghargai dan menghormati orang lain, tidak membeda-bedakan, dan bergaul dengan semua teman. Salah satu visi dalam Yayasan Melania adalah mencerdaskan kehidupan bangsa tanpa membedakan suku, agama dan keturunan.

Salah satu misi yang diperjuangkan oleh Yayasan Budi Mulia Lourdes adalah menciptakan sikap saling menghargai dan berdialog dengan lembaga lain. Dengan demikian SD Budi Mulia juga memiliki perjuangan untuk terbuka bagi lembaga lain. 


\subsubsection{Pembelajaran dengan Aktivitas}

Dalam rangka merayakan Bulan Kitab Suci Nasional, SD Strada Van Lith I mengajak para orangtua murid dari berbagai latar belakang agama yang berbeda untuk membuka stand-stand yang memperkenalkan agama mereka masingmasing. Stand tersebut menampilkan Kitab Suci dan hal-hal yang berhubungan dengan identitas agama masing-masing. Para siswa diajak untuk mengunjungi stand-stand tersebut dan dipersilakan untuk bertanya.

SD Tarakanita $\mathrm{V}$ mengadakan retret bagi kelas 6. Retret itu memasukkan unsur pembinaan karakter dalam Cc 5. Dalam pelajaran Religiusitas, anak-anak dari latar belakang agama yang berbeda diajak untuk membagikan pengalaman rohani mereka masing-masing. Kekhasan buku pelajaran Religiusitas adalah anak yang diajak untuk aktif dalam pelajaran sehingga banyak pengalaman yang didapat oleh anak.

\subsubsection{Pembelajaran dengan Pengalaman Sosial}

Dalam rangka menumbuhkan jiwa solider anak dan penghormatan kepada semua orang, SD Strada Van Lith I mengadakan bakti sosial bagi masyarakat di Kali Ciliwung tanpa membedabedakan agama atau suku. Dalam rangka keterbukaan pada orang yang berbeda agama, saat bulan puasa yang dilaksanakan oleh umat Muslim, SD Taraknita V mengadakan acara buka puasa bersama. Mereka mengundang orangtua murid dan masyarakat setempat. Kegiatan buka bersama ini memberi peluang interaksi antar umat beragama.

Lantaran kurangnya pendidikan toleransi dan pluralisme yang dirasakan oleh SD Melania II, sekolah mengadakan kegiatan-kegiatan yang mendukung anak menjadi siswa-siswi yang terbuka dan toleran. Salah satu kegiatannya adalah mengunjungi wisma tuna ganda Palsigunung Depok yang dimiliki oleh yayasan Islam. Mereka membuat kegiatan sosial yang tidak biasa, artinya tidak mengunjungi panti-panti yang dikelola oleh yayasan Katolik.

Bapak Agustian mengajak siswa-siswi SD Melania untuk mengunjungi rumah singgah yang dikelola oleh para pastor OFM. Rumah singgah itu adalah tempat berkumpul orang miskin, gelandangan, pengamen atau pengemis. Di sana siswa-siswi belajar untuk saling membantu orang yang miskin tanpa membeda-bedakan suku, ras dan agama. Kegiatan ini pun didukung oleh orangtua murid.
Berdasarkan data buku-buku yang ada, ${ }^{11}$ nampak jelas bahwa unsur pembelajaran lewat pengalaman kurang nampak. Hanya unsur pembelajaran penghilangan sifat egoisme anak dibahas paling banyak. Peran sekolah dalam menyediakan wadah agar anak memiliki pengalaman berinteraksi dengan keberagaman agama dan suku menjadi besar di sini karena buku-buku kurang menyediakan sarana tersebut. Hanya dalam buku religiusitas Menjadi Anak Beriman yang Terbuka, anak-anak mendapatkan pembelajaran melalui pengalaman.

Dengan membandingkan porsi pendidikan toleransi dan pluralisme dalam buku pelajaran agama dan religiusitas dengan buku pelajaran PKn, nampak jelas bahwa pendidikan PKn sangat kurang porsinya. Dalam rentang 6 tahun masa sekolah di sekolah dasar, PKn hanya kurang lebih 15 kali membahas tentang tema yang berbicara tentang toleransi atau pluralisme. Sedangkan buku pendidikan religiusitas membahas tema tersebut kurang lebih 30 kali. Kelebihan dari pendidikan religiusitas adalah adanya keaktifan dan interaksi dari para siswanya. Dan buku pelajaran pendidikan agama Katolik mengajarkan tema toleransi dan pluralisme sebanyak 38 kali selama masa pendidikan di sekolah dasar.

\subsection{Kerangka Pikir Tahap Perkembangan Moral Lawrence Kohlberg dalam Data}

Penekanan Piaget atas pentingnya interaksi aktif yaitu pengalaman dan aktivitas antara subjek dan lingkungan dinamisnya merupakan gagasan utama yang menjadi dasar pendekatan kognitif developmental struktural Kohlberg. Kohlberg menganjurkan agar pengembangan moral anak dilakukan dengan contoh-contoh dan instruski yang memberikan stimulus bagi anak untuk berpikir. $^{12}$ Dalam tahap perkembangan moral menurut Kohlberg, anak-anak sekolah dasar masuk dalam kategori tahap awal yaitu tahap I atau tingkat I yang disebut dengan tahap Penalaran Prakonvensional.

\subsubsection{Tingkat Satu: Penalaran Prakonvensional $^{13}$}

Pada umumnya anak yang berada pada tahap ini adalah anak yang berusia 10-13 tahun. ${ }^{14}$ Anak tidak memperlihatkan adanya internalisasi nilainilai moral. Anak tanggap terhadap aturan-aturan budaya dan terhadap ungkapan-ungkapan budaya mengenai hal yang baik dan yang buruk, hal yang benar dan yang salah. Akan tetapi baik atau buruk dan benar atau salah diinterpretasikan dari segi 
akibat fisik atau kenikmatan dari perbuatannya. Hal ini nampak dalam penalaran moral yang dikendalikan oleh imbalan atau hadiah dan hukuman atau pertukaran kebaikan.

\subsubsection{Tahap I: Orientasi Hukuman dan Ketaatan}

Yang menentukan baik atau buruknya tindakan itu adalah konsekuensi-konsekuensi fisik atas tindakan, entah apa pun arti atau nilai akibatakibat itu bagi manusia. Anak hanya semata-mata menghindari hukuman dan tunduk pada kekuasaan, dengan tanpa mempertanyakannya, memiliki nilai pada dirinya sendiri. Tindakan terjadi pada anak bukan atas dasar hormat pada peraturan moral yang mendasarinya tetapi tindakan itu dilatarbelakangi oleh hukuman dan otoritas. Penalaran moral yang ada didasarkan atas hukuman dan anak taat karena orang dewasa menuntut mereka untuk taat. ${ }^{15}$

\subsubsection{Tahap II: Orientasi Relativis Instrumental}

Pada tahap ini penalaran moral didasarkan atas imbalan atau hadiah dan demi kepentingan diri sendiri. Perbuatan yang benar adalah perbuatan yang menjadi cara untuk menguntungkan kebutuhan diri sendiri meski kadang kala juga kebutuhan orang lain. ${ }^{16}$ Anak-anak akan taat apabila tindakan yang paling menguntungkan diri sendiri adalah taat. Apa yang benar adalah apa yang dirasakan baik dan apa yang dianggap menghasilkan hadiah. Hubungan manusia dianggap seperti hubungan di pasar yaitu penjual yang mendapat keuntungan dan pembeli yang mendapat barang. Ada unsur timbal balik. Ia harus menerima jika telah memberi.

Dalam data penelitian, umumnya anak-anak kelas 1 sampai dengan kelas 3 belum memiliki pemikiran logis yang memadai sehingga ketika ditanya mengenai alasan mengapa setiap orang harus menghargai dan menghormati orang lain, mereka tidak dapat menjawab pertanyaan (atau: jawaban yang diberikan tidak sambung dengan pertanyaan). Mereka yang masuk dalam tahap Penalaran Prakonvensional adalah anak-anak yang masih berpikir dengan kerangka pikir boleh atau tidak boleh, dilarang atau tidak dilarang, demi keuntungan pribadi. Ada anak kelas satu yang dapat masuk dalam kategori ini karena proses belajarnya lebih cepat dibanding yang lain.

Selain mereka berada dalam tahap I, ada beberapa anak yang mulai keluar dari dirinya sendiri dalam memahami permasalahan moral. Anak mulai membangun motivasi bukan lagi hanya untuk diri sendiri tetapi demi kebaikan bersama. Ada alasan-alasan yang muncul dari jawaban anak yang cukup menunjukkan keterbukaan seperti: demi terciptanya kerukunan hidup bersama, perhormatan pada setiap hak pribadi manusia, kesetaraan manusia sebagai ciptaan, dan terjaminnya hak asasi manusia. Mereka juga mulai memahami bahwa syarat menjadi seorang pemimpin tidak terletak pada latar belakang agamanya tetapi karena kemampuannya. Semua ini tergantung bagaimana siswa belajar dari pengalaman dan bagaimana proses adaptasinya berjalan. Dapat dikatakan, anak dalam kelompok ini sudah mulai masuk dalam tahap II yaitu Penalaran Konvensional.

\subsubsection{Realitas Pendidikan Toleransi dan Pluralisme dalam Kerangka Pikir Kohlberg}

Menurut Kohlberg, pengalaman sosial-lah yang dapat membuat moral anak berkembang. Keempat sekolah yang diteliti umumnya berusaha agar setiap anak memiliki pengalaman sosial yang baik. Hal itu nampak dalam kegiatan yang melibatkan orang dari berbagai latar belakang agama yang berbeda. Seperti yang sudah dibahas dan diungkapkan dalam poin realitas pendidikan keterbukaan dan keberagaman dalam kerangka pikir Piaget di atas, keempat sekolah ini mencoba mempertemukan anak-anak dari berbagai latar belakang agama yang berbeda.

Dalam mengajarkan tentang perbedaan suku dan agama, SD Strada Van Lith I memiliki maketmaket suku-suku dan agama-agama. Dengan melihat maket-maket, anak dapat secara langsung atau visual mampu melihat perbedaan-perbedaan atau keberagaman yang ada. Pengalaman langsung ini membuat para siswa dapat bersikap terhadap perbedaan dan keragaman yang ada.

Dalam Pendidikan Religiusitas Di SD Tarakanita V, ada kesempatan sharing dari para murid dari latar belakang agama yang berbeda tentang pengalaman rohani mereka masingmasing. Bapak Yolam sebagai kepala sekolah SD Budi Mulia pernah memberikan pelajaran dengan memberi contoh langsung kepada pribadi-pribadi yang berbeda.

Keempat sekolah ini juga mengupayakan agar pengalaman sosial, yang sering juga terkait dengan pembelajaran melalui aktivitas, di sekolah mereka seperti SD Strada Van Lith I melibatkan orangtua murid untuk membuka stand-stand yang memperkenalkan agama mereka masing-masing. SD Strada Van Lith I pun mengadakan bakti sosial 
bagi masyarakat di Kali Ciliwung. SD Taraknita V mengadakan acara buka puasa bersama dengan mengundang masyarakat setempat dan tokohtokoh yang beragama Islam. SD Melania II mengunjungi wisma tuna ganda Palsigunung Depok yang merupakan yayasan bercorak Islami. Bapak Agustian mengajak siswa-siswi SD Melania untuk mengunjungi rumah singgah di Tanah Tinggi Jakarta Pusat. Rumah singgah itu terbuka bagi orang miskin, gelandangan, pengamen atau pengemis dari berbagai latar belakang agama dan suku.

\subsection{Kerangka Pikir Tahap Perkembangan Iman James Fowler dalam Data}

Fowler memiliki pandangan bahwa perkembangan manusia dipengaruhi oleh beberapa faktor. Sebagaimana dalam pandangan Piaget, manusia mencari keseimbangan ketika terjadi ketidakseimbangan dalam hidup. ${ }^{17}$

Faktor-faktor yang mempengaruhi keseimbangan tersebut adalah kematangan biologis. Faktor kematangan biologis ini adalah faktor yang fundamental. Ketika otak semakin matang untuk bekerja, maka proses berpikir pun dapat berkembang. Faktor kedua adalah perkembangan kognitif. Perkembangan ini membantu manusia dalam merasa, mengkonstruksi, menafsirkan dan mengerti pengalaman. Oleh karena itu, manusia dapat mengingat masa lalu dan mengantisipasi masa depan. ${ }^{18}$

Faktor ketiga yang berpengaruh adalah kematangan emosional dan afektif. Hal ini berkaitan dengan rasa perasaan. Faktor keempat adalah kapasitas tanggung jawab moral dan sosial serta perkembangan dalam iman. ${ }^{19}$ Perkembangan iman sendiri dipengaruhi oleh perjumpaan pengalaman ambang batas hidup manusia yang dipengaruhi oleh ajaran-ajaran agama dan dukungan serta dorongan dari komunitas iman. ${ }^{20}$ Dengan demiki-an, perkembangan iman seseorang merupakan proses pencarian keseimbangan berdasarkan perjumpaan pengalaman yang dibenturkan pada ajaran agama yang telah dipelajari serta pengaruh-pengaruh orang lain di lingkungan sekitarnya.

Dalam pandangan Fowler, anak-anak sekolah dasar berada pada tahap akhir Tahap Iman IntuitifProyektif dan Tahap Iman Mitis-Literal serta awal Tahap Iman Sintetis- Konvensional.

\subsubsection{Masa Sekolah Dasar: Akhir Tahap Iman Intuitif-Proyektif, Tahap Iman Mitis Literal, dan Awal Tahap Iman Sintetis Konvensional}

\subsubsection{Akhir Tahap Iman Intuitif-Proyektif}

Tahap Intuitif-Proyektif ini dialami oleh orang yang berusia sekitar 3-7 tahun sedangkan siswa sekolah dasar berada pada rentang umur antara 612 tahun. Oleh karena itu, anak yang berumur 6-7 tahun masih berada pada tahap Iman Intuitif Proyektif. Pada tahap ini, pola pemikiran anak masih labil. Kelabilan ini masih sangat wajar mengingat anak berjumpa dengan hal-hal baru dalam kondisi belum memiliki pengetahuan iman yang terpatri secara mendalam. Kekhasan dalam tahap ini, anak mulai membentuk dan mengingat apa yang ada di luar dirinya sebagai modal hidupnya di dunia ini. Hidupnya dipenuhi oleh imajinasi dan fantasi. Bahkan, logika anak tidak dapat membatasi dan menghalangi imajinasi dan fantasi anak. Penyampaian dasar tentang iman yang paling baik adalah dengan menggunakan cerita-cerita, gerak isyarat dan simbol-simbol yang berkaitan dengan pengajaran iman. ${ }^{21}$

\subsubsection{Tahap Iman Mitis Literal}

Tahap Perkembangan Iman Mitis Literal ini berlangsung sekitar usia 7 tahun sampai 12 tahun. ${ }^{22}$ Ciri dari perkembangan di tahap ini adalah adanya peningkatan akurasi dalam melihat perspektif orang lain. Anak-anak mulai membedakan hal-hal yang logis atau nyata dengan hal-hal yang bersifat khayalan. Meskipun belum mempunyai kemampuan abstraksi dan refleksi secara matang, mereka sudah mulai dapat menangkap makna cerita-cerita dan kepercayaan. Makna kehidupan tersebut mulai mereka temukan dalam cerita-cerita atau dongeng keagamaan. Ketika mulai menemukan makna dalam ceritera, pada tahap ini anak-anak juga mulai bersikap kritis terhadap cerita-cerita atau dongeng tersebut. Benturan ilmu pengetahuan dan Kitab Suci pun dapat mereka temui misalnya benturan antara teori evolusi Darwin dengan kisah penciptaan dalam Kitab Kejadian. ${ }^{23}$

Orang yang berada dalam tahap kedua ini menyusun dunianya berdasarkan prinsip keadilan timbal balik dan keadilan yang imanen berdasarkan pembalasan terhadap apa yang telah diperbuat. ${ }^{24}$ Mereka akan merasa aman memeluk satu iman kepada Tuhan karena mereka melihat bahwa Tuhan itu adalah sesuatu yang setia. Penjelasan yang logis dan memadai pada tahap ini menjadi penting mengingat anak mulai belajar berpikir kritis dan logis. 


\subsubsection{Awal Tahap Iman Sintetis Konvensional}

Tahap Iman Sintetis Konvensional ini juga sering disebut dengan tahap iman penyesuaian (conforming faith). Mereka yang mengalami tahap ini dialami adalah remaja dan orang yang beranjak dewasa. Rentang umur pada tahap ini adalah mereka yang berumur antara 12-20 tahun. ${ }^{25}$ Tahap ini berarti dimulai pada umur akhir sekolah dasar yaitu sekitar umur 12 tahun. Poin utama dalam tahap ini adalah hubungan antar pribadi yang menjadi bagian krusial dalam proses perkembangan iman mereka secara pribadi dan kelompok. Mereka sudah memiliki "ideologi” tentang nilainilai dan iman akan tetapi belumlah sungguhsungguh direfleksikan secara mendalam. Sifat komformistis remaja dalam menggali identitas dirinya yang memungkinkan ini. Remaja pada umumnya mengidentifikasi dirinya serupa dengan pandangan dan pengartian orang lain atau masyarakat karena identitas diri mereka dibentuk berdasarkan perasaan dipercaya dan diteguhkan oleh orang lain. Oleh karena itu, remaja berjuang mencari keseimbangan yaitu dilema antara tuntutan identitas diri yang otentik dengan harapan-harapan orang lain. ${ }^{26}$ Oleh karena itu, sangatlah diperlukan peranan pihak luar yang memberikan teladan dan penuntun hidup bagi remaja.

Berdasarkan keterangan di atas, penulis menyimpulkan beberapa hal yang penting dalam pendidikan toleransi dan pluralisme pada usia sekolah dasar. Pertama adalah sarana pembelajaran melalui cerita-cerita, gerak isyarat dan simbolsimbol. Kedua, penjelasan cerita-cerita dan dongeng yang memadai serta logis. Ketiga, keteladanan para pendidik dan orang lain di sekitarnya. Pendidikan toleransi atau keterbukaan dan pluralisme pada masa sekolah dasar membutuhkan ketiga hal tersebut.

Siswa-siswi dari keempat sekolah yang diteliti umumnya lahir antara tahun 2001 sampai 2006. Dengan demikian, mereka umumnya berumur antara 6-12 tahun. Maka sebagian besar anak berada dalam Tahap Iman Mitis Literal yang rentang umurnya dari 7-12 tahun. Akan tetapi melihat pandangan Piaget dan Kohlberg yang menyatakan bahwa pemikiran logis yang cukup memadai dimulai saat berumur 10 tahun atau kelas 4 SD maka dapat dikatakan juga mereka yang masih duduk di kelas 1 sampai dengan kelas 3 masih berada dalam Tahap Iman Intuitif Proyektif. Sedangkan mereka yang sudah berumur 12 tahun mulai masuk Tahap Iman Sintetis Konvensional.

\subsubsection{Realitas Pendidikan Toleransi dan Pluralisme dalam Kerangka Pikir Fowler}

Bagi Fowler, anak-anak yang duduk di sekolah dasar dapat dididik dengan cara memberikan cerita-cerita, gerak isyarat dan simbol-simbol yang berkaitan dengan pengajaran iman. Cara tersebut cocok untuk kelas 1 sampai kelas 3. Kemudian, penjelasan yang logis dan memadai dalam mengajar diperlukan pada saat kelas 4 sampai kelas 6. Dan, ketika sudah menginjak kelas 6, keteladanan dari para guru semakin dibutuhkan.

Umumnya dalam mengajarkan toleransi dan pluralisme, para guru dari keempat sekolah sudah menggunakan cerita-cerita, gerak isyarat dan simbol-simbol sebagai bahan mengajar. Seperti yang dilakukan oleh Ibu Astuti, Guru Agama SD Strada Van Lith I, ia menggunakan contoh-contoh, cerita-cerita dan maket-maket untuk memahami pentingnya hidup dalam keberagaman. Bapak Yolam sebagai kepala sekolah SD Budi Mulia pernah memberikan pelajaran dengan memberi contoh langsung kepada pribadi-pribadi yang berbeda seperti yang diungkapkan oleh Vita.

Umumnya buku-buku pelajaran yang digunakan, baik Pelajaran Agama, Pelajaran Religiusitas dan PKn, sudah memuat contohcontoh dan cerita. Hal itu nampak dalam buku Menjadi Sahabat Yesus untuk Kelas 2. Ada lebih dari 30 cerita yang disampaikan. Berkaitan dengan keteladanan, umumnya para guru di sekolah Katolik adalah guru yang terbuka dan toleran. Mereka memberikan contoh hidup sehari-hari seperti yang nampak dalam ungkapan anak-anak yang meniru gurunya.

\subsection{Pandangan "Gravissimum Educationis" (GE) terhadap Pendidikan}

$G E$ tidak banyak secara spesifik menunjukkan pandangannya tetang pendidikan toleransi dan pluralisme di sekolah-sekolah. Akan tetapi, garisgaris yang umum yang mau diangkat oleh Konsili menyiratkan pendidikan keterbukaan akan keberagaman. Garis-garis umum yang ditekankan Konsili terletak pada GE artikel 1. Tekanan utama artikel itu adalah bahwa pendidikan hendaknya dapat membawa pada kesejahteraan umum, cinta kasih sesama manusia, terlibat dalam kehidupan sosial, persaudaraan dan perdamaian duniaserta yang terbuka bagi semua orang.

Semua sekolah yang diteliti oleh penulis telah mengupayakan pendidikan yang membawa pada kesejahteraan umum, cinta kasih kepada sesama 
manusia, persaudaraan dan perdamaian dunia serta terbuka bagi semua orang. Hal itu nampak dalam visi dan misi sekolah-sekolah tersebut yang mendidik para siswa-siswi untuk mempersiapkan diri dalam bertanggungjawab untuk menciptakan kesejahteraan umum, memupuk cinta kasih terhadap sesama, terbuka pada keberagaman dan menciptakan persaudaraan sejati.

Dengan pendidikan yang diberikan oleh beberapa SD Katolik ini, para siswa menjadi siswa yang toleran dan terbuka. Hal itu nampak dalam data di mana seluruh siswa terbuka pada orang lain yang berbeda. ${ }^{27}$ Sebagian besar responden mau duduk bersebelahan dengan teman yang berbeda suku atau agama (97.2\%). ${ }^{28}$ Sebagian Sebagian besar responden mau dipimpin oleh ketua kelas yang berbeda agama dengannya (96.0\%). besar responden memiliki teman yang berbeda agama dengannya (96.2\%). ${ }^{29}$

\section{KESIMPULAN}

Berdasarkan analisa di atas, penulis menghasilkan sintesa bahwa sekolah-sekolah dasar Katolik sebagai pendidik toleransi dan pluralisme berdasar pada kerangka teori Jean Piaget, Lawrence Kohlberg dan James W. Fowler serta deklarasi GE. Oleh karena itu, sekolah-sekolah dasar Katolik adalah sekolah-sekolah dasar yang terbuka dan toleran, bukan tertutup.

Pendidikan toleransi dan pluralisme yang baik adalah yang memenuhi syarat-syarat dalam teoriteori perkembangan kognitif, moral dan iman menurut ketiga tokoh tersebut di atas. Hal itu termasuk dalam pengajaran para guru, buku-buku, materi pendidikan, porsi pelajaran, cara mengajar, dan teladan pengajar yang baik. Ketika hal-hal tersebut terpenuhi, maka peluang para siswa-siswi menjadi pribadi yang terbuka dan toleran dapat tercapai.

Dengan kata lain, penulis mau mengatakan bahwa pendidikan toleransi dan pluralisme yang baik itu adalah pendidikan interreligiusitas. Pendidikan interreligiusitas adalah pendidikan yang membawa setiap siswa kepada perjumpaan dengan keberagaman baik agama, suku, maupun ras. Oleh karena itu dapat dikatakan bahwa pendidikan interreligiusitas mengantar siswa-siswi menjadi insan yang terbuka dan toleran. Pendidikan interreligiusitas ini dapat dimasukkan dalam kurikulum pendidikan agama dan pendidikan kewarganegaraan serta program sekolah.

Bagi penulis, pendidikan interreligiusitas ini, berdasarkan inspirasi dari Piaget, Kohlberg dan Fowler, dan pesan Perjanjian Lama, Perjanjian
Baru, serta GE, membuka peluang bagi para peserta didik di sekolah dasar untuk mendapatkan beberapa hal berikut:

Pertama adalah perjumpaan dan pengalaman kebersamaan. Perjumpaan yang dimaksud adalah pengalaman konkret perjumpaan dengan keberagaman baik dari segi agama, suku dan ras. Perjumpaan dan pengalaman kebersamaan membuat setiap perserta didik dapat mengalami secara langsung hidup bersama dengan orang-orang yang berbeda. Perjumpaan ini memberi stimulus bagi setiap orang untuk mengambil sikap. Dengan pendampingan yang baik, para siswa dapat menyikapi perbedaan yang ada dengan saling menerima dan menghormati perbedaan.

Kedua adalah pengetahuan. Setelah ada perjumpaan, para siswa dapat diberi pengetahuan yang cukup untuk memahami perbedaanperbedaan yang ada. Pengetahuan ini, dalam kerangka pikir Piaget, adalah pengetahuan yang menghilangkan sifat egosentrisme. ${ }^{30}$ Dalam hal agama, para siswa dapat dibekali pengetahuan umum bahwa semua agama menghendaki kedamaian. Para siswa pun dapat diberikan ajaran agama-agama yang ada yang memiliki kesamaan dalam cita-citanya yaitu mengupayakan keadilan dan kesejahteraan masyarakat. ${ }^{31}$ Perbedaanperbedaan yang ada diajarkan sebagai pengetahuan dan perlu dihargai dan dihormati.

Ketiga adalah sharing dan dialog. Setelah ada perjumpaan dan pengetahuan, pihak-pihak yang berbeda dapat saling membagikan pengalaman dan pandangannya masing-masing terkait ciri khas mereka dan ciri khas orang lain. Berbekal pengetahuan yang baik, dialog dapat terjadi sehingga masing-masing siswa yang berbeda dapat hidup berdampingan karena saling menerima dan menghargai perbedaan yang ada.

Kesemuanya adalah proses untuk mencapai ekuilibrasi yang melalui tahap asimilasi dan akomodasi. Proses-proses itu dibuat berdasarkan tahap perkembangan anak baik dari Piaget, Fowler maupun Kohlberg sehingga pemberian pengalaman, pengetahuan dan sharing serta dialog diberikan sesuai dengan tahap-tahap perkembangan anak.

\section{PENUTUP}

Manusia adalah makhluk sosial. Ia tidak dapat hidup sendiri. Dalam hidup bersama, tentu mereka memiliki perbedaan-perbedaan, mulai dari fisik, gaya berbicara, kesukaan, cara berpakaian dan lain sebagainya. Setiap pribadi itu unik. Oleh karena itu, pada dasarnya manusia itu beragam. Yang 
menyatukan adalah eksistensinya sebagai sesama manusia. ${ }^{32}$ Maka, hidup dalam keberagaman merupakan sesuatu yang tidak dapat dihindari.

Indonesia adalah negara yang mempunyai banyak agama, ras dan sukunya. Ada enam agama yang diakui yaitu Islam sebagai mayoritas, Katolik, Kristen, Hindu, Buddha dan Konghucu. Ada banyak aliran kepercayaan yang tersebar di seluruh nusantara. Dalam survey Badan Pusat Statistik (BPS), jumlah suku bangsa di Indonesia terhitung sampai dengan 3 Februari 2010 diketahui terdiri dari 1.128 suku. ${ }^{33}$ Masing-masing suku bangsa memiliki budaya dan bahkan bahasanya sendiri.

Banyaknya pertikaian dan perselisihan karena SARA dapat mengancam kesatuan bangsa. Harus ada upaya yang dapat menciptakan kondisi yang kondusif bagi kerukunan seluruh masyarakat Indonesia. Jalan-jalan dialog tentu kerap diupayakan oleh pihak-pihak yang berwenang ketika konflik sudah terjadi. ${ }^{34}$ Akan tetapi upaya yang lebih sistematis dan preventif perlu diupayakan sejak dini. Melalui pendidikanlah upaya tersebut dapat ditempuh. Sedari kecil, setiap orang harus sudah diajarkan untuk menghargai dan menghormati yang berbeda.

Oleh karena itu, pendidikan interreligiusitas menjadi perlu dan penting bagi masyarakat di Indonesia karena mendidik para siswanya menjadi anak yang memiliki keterbukaan moral, menghargai dan menerima perbedaan. Pendidikan interreligiusitas ini penting terutama dimulai dari para pelajar di sekolah dasar karena pada saat itulah secara kognitif mereka mulai dapat menghilangkan sifat egosentrisme dan memiliki logika yang memadai. Peran guru dalam membimbing dapat mengantar anak pada tujuantujuan yang sifatnya bukan hanya pada bidang intelektualitas tetapi juga kemampuan hidup bersama dengan orang lain, sikap menghormati kepentingan dan harga diri orang lain dan caracara mengatasi kesulitan dirinya. ${ }^{35}$

Dalam realitas, seorang anak kira-kira sehari berada di lingkungan sekolah selama 5-6 jam. Jika waktu tidur anak dihitung sekitar 8-9 jam maka ada sekitar 15 jam ia dalam keadaan tidak tidur di mana sepertiga waktunya dihabiskan di sekolah. Guru berada dalam lingkungan yang dekat dengan anak maka pengaruh guru begitu besar dalam pembentukkan patokan-patokan hidup, sikapsikap dan tingkah laku yang dicita-citakan. ${ }^{36}$

Dengan demikian, dalam perspektif teori Piaget, Kohlberg dan Fowler serta dalam spiritualitas GE, sekolah memiliki semacam 'keharusan' untuk memperkenalkan setiap perbedaan untuk menciptakan toleransi dan kerukunan. Perkenalan itu dapat terwujud baik dalam pendidikan agama yang memasukkan unsur interreligiusitas dan pendidikan kewarganegaraan. Pendidikan agama menekankan nilai-nilai kebenaran dalam agama dan sifatnya dogmatis akan tetapi pendidikan interreligiusitas mengajarkan nilai-nilai kemanusiaan yang terdapat dalam berbagai kekayaan rohani agama-agama.

Dalam rekomendasi PBB, ada dua syarat yang penting yang menjadi tujuan yang sah untuk suatu pendidikan agama bersama dalam masyarakat yang pluralistik. Pertama, program-program pendidikan agama bersama di sekolah harus berusaha keras membantu perkembangan toleransi, tanpa melanggar hak kebebasan beragama atau keyakinan. Kedua, programprogram sekolah tersebut harus didesain untuk memajukan sikap menghormati hak asasi universal dan martabat manusia yang sederajat. ${ }^{37}$ Dengan demikian, kepentingan publik dan kepentingan pribadi atau orangtua dapat ditampung di sekolah.

Yang menjadi penting bagi sekolah swasta yang berlandaskan agama adalah bahwa mereka tetap menjamin adanya pendidikan interreligiusitas yang menghargai agama setiap siswa. Jika ada orang non Kristiani yang bersekolah di sekolah Katolik, orangtuanya telah lebih dahulu diberi penjelasan bahwa di sekolah tersebut akan ada pelajaran agama Katolik, akan tetapi sekolah tetap memasukkan pendidikan interreligiusitas yang membentuk para siswa-siswi menjadi siswa yang toleran, menghargai perbedaan dan mau menciptakan kerukunan bersama. Pendidikan agama Katolik dapat dipahami sebagai pengetahuan bagi siswa-siswi non Katolik.

\section{Paulus Dwi Hardianto}

Rohaniwan Katolik, berkarya di sebuah paroki di Keuskupan Agung Jakarta; Alumnus Program Magister Teologi Universitas Sanata Dharma: dwi.hardianto.paulus@gmail.com

\section{CATATAN AKHIR}

Lih. "Intoleransi Agama Bakal Terus Meningkat”, http://www.theindonesianway.com/2012/05/26/8741/intoleransi -agama-makin-meningkat, diunduh Senin, 24 September 2012 pukul 18.00 .

Dikutip dari artikel "Kasus GKI Taman Yasmin, Pelarangan Ibadah Tidak Boleh Dilakukan”, http://www.suarapembaruan.com/home/kasus-gki-tamanyasmin-pelarangan-ibadah-tidak-boleh-dilakukan/5784, diunduh Minggu 18 Des 2011 pukul 07.20. 
E. Maulia, "Islamic Teachers 'Lack Pluralistic Perspective", dalam Jakarta Post 27 November 2008.

4 Lih. A. Woolfolk, Educational Psychology Active Learning Edition, 52.

5 Lih. A. Woolfolk, Educational Psychology Active Learning Edition, 55.

Lih. J. Piaget, Six Psychological Studies, 38.

A. Woolfolk, Educational Psychology Active Learning Edition, 53.

J. Piaget, Six Psychological Studies, 39.

$9 \quad$ Lih., P. Dwi Hardianto, "Pendidikan Berbasis Toleransi dan Pluralisme: Studi Kasus dan Penelitian atas Beberapa Sekolah Dasar Katolik di Jakarta Tahun 2013”, 161-163.

10 L. Prasetya, Pr. dkk. (Ed.), Menjadi Anak Beriman Yang Terbuka Untuk Sekolah Dasar Kelas I, vi.

11 Lih. P. Dwi Hardianto, Pendidikan Berbasis Toleransi dan Pluralisme: Studi Kasus dan Penelitian atas Beberapa Sekolah Dasar Katolik di Jakarta Tahun 2013, 2014, Yogyakarta, Universitas Sanata Dharma, 171-183.

12 Lih. R. S. Peter, Moral Development and Moral Education, 8990.

13 Lawrence Kohlberg, "Stages of Moral Development as a Basis for Moral Education”, 91.

14 R. Duska dan M. Whelan, Perkembangan Moral Perkenalan dengan Piaget dan Kohlberg, 65.

15 John de Santo dan Agus Cremers (penerj.), Tahap-Tahap Perkembangan Moral Lawrence Kohlberg, 231.

Ibid.

J. W. Fowler, Faith Development and Pastoral Care, 101

J. W. Fowler, Faith Development and Pastoral Care, 101-102.

J. W. Fowler, Faith Development and Pastoral Care, 102.

J. W. Fowler, Faith Development and Pastoral Care, 115.

J. W. Fowler, Stages Of Faith The Psychological of Human Development and the Quest for Meaning, Harper \& Row, San Fransisco, 133. Bdk. A. Supratiknya, (ed.), Teori Perkembangan Kepercayaan, 28.

22 A. Supratiknya, (ed.), Teori Perkembangan Kepercayaan Karya-Karya Penting James W. Fowler, 29.

23 J. W. Fowler, Stages Of Faith The Psychological of Human Development and the Quest for Meaning, 150.

24 James W. Fowler, Stages Of Faith The Psychological of Human Development and the Quest for Meaning, 149.

25 A. Supratiknya, (ed.), Teori Perkembangan Kepercayaan Karya-Karya Penting James W. Fowler, 30.

26 J. W. Fowler, Stages Of Faith The Psychological of Human Development and the Quest for Meaning, 172-173.

27 P. Dwi Hardianto, Pendidikan Berbasis Toleransi dan Pluralisme, 134.

28 P. Dwi Hardianto, Pendidikan Berbasis Toleransi dan Pluralisme, 141.

29 P. Dwi Hardianto, Pendidikan Berbasis Toleransi dan Pluralisme, 144.

$30 \quad$ J. Piaget, Six Psychological Studies, 39.

31 Bdk. I. Haryanto dan P. Benedanto, Terbuka terhadap Sesama Umat Beragama Aktualisasi Ajaran Sosial Gereja tentang Agama yang Inklusif, 27-31.

32 Bdk. Louis Leahy, Siapakah Manusia?, 15-16.

33 "Indonesia Miliki 1.128 Suku Bangsa”, http://m.jpnn.com/news.php?id=57455, diunduh tanggal 11 Oktober 2013 pukul 16.00 .

34 Jussuf Kalla saat menjadi Wakil Presiden Indonesia pernah menjadi perantara perdamaian untuk menciptakan dialog saat konflik antar agama, etnik dan golongan. "Jusuf Kalla : Jangan Bosan Mengemong Warga Poso",

http://m.tribunnews.com/regional/2013/08/14/jusuf-kallajangan-bosan-mengemong-warga-poso, diunduh pada tanggal 13 Oktober 2013 pukul 07.00.

35 Bdk. Y. Singgih D. Gunarsa, Psikologi untuk Membimbing, 25

36 Y. Singgih D. Gunarsa, Psikologi untuk Membimbing, 97.

37 I. Plesner, Memajukan Toleransi Melalui Pendidikan Agama, 673.

\section{DAFTAR RUJUKAN}

\section{Internet}

“Intoleransi Agama Bakal Terus Meningkat”, http://www.theindonesianway.com/2012/05/2 6/8741/intoleransi-agama-makin-meningkat, diunduh Senin, 24 September 2012 pukul 18.00.

“Kasus GKI Taman Yasmin, Pelarangan Ibadah Tidak Boleh Dilakukan”, http://www.suarapembaruan.com/home/kasusgki-taman-yasmin-pelarangan-ibadah-tidakboleh-dilakukan/5784, diunduh Minggu 18 Des 2011 pukul 07.20.

“Indonesia Miliki 1.128 Suku Bangsa”, http://m.jpnn.com/news.php?id=57455, diunduh tanggal 11 Oktober 2013 pukul 16.00.

Jusuf Kalla saat menjadi Wakil Presiden Indonesia pernah menjadi perantara perdamaian untuk menciptakan dialog saat konflik antar agama, etnik dan golongan. "Jusuf Kalla : Jangan Bosan Mengemong Warga Poso”, http://m.tribunnews.com/regional/2013/08/14/jusuf-kalla-jangan-bosanmengemong-warga-poso, diunduh pada tanggal 13 Oktober 2013 pukul 07.00.

\section{Artikel}

Maulia, Erwida, "Islamic Teachers 'Lack Pluralistic Perspective”, dalam Jakarta Post 27 November 2008.

Plesner, Ingvill Thorson, "Memajukan Toleransi Melalui Pendidikan Agama”, dalam Kebebasan Beragama atau Berkeyakinan, Kanisius, Yogyakarta, 2010.

\section{Buku}

Benedanto, P. dan I. Haryanto, 2004. Terbuka terhadap Sesama Umat Beragama Aktualisasi Ajaran Sosial Gereja tentang Agama yang Inklusif. Yogyakarta: Kanisius.

Cremers, A. dan John de Santo (penerj.), 1995. TahapTahap Perkembangan Moral Lawrence Kohlberg. Yogyakarta: Kanisius.

Fowler, J. W., 1987. Faith Development and Pastoral Care, Philadelphia: Fortress Press.

Fowler, J. W., 1995. Stages of Faith: The Psychological of Human Development and the Quest for Meaning. San Fransisco: Harper \& Row.

Gunarsa, Y. Singgih D., 1980. Psikologi untuk Membimbing. Jakarta: BPK Gunung Mulia.

Hardianto, P. Dwi, 2014. Pendidikan Berbasis Toleransi dan Pluralisme: Studi Kasus dan Penelitian atas Beberapa Sekolah Dasar Katolik di Jakarta Tahun 2013. Yogyakarta: Universitas Sanata Dharma. 
Kohlberg, L., "Stages of Moral Development as a Basis for Moral Education”, dalam Brenda Munsey (ed.), Moral Developtment, Moral Education, and Kohlberg. Birmingham: Religious Education Press.

Leahy, L., 2001. Siapakah Manusia?. Yogyakarta: Kanisius.

Peter, R. S., 1981. Moral Development and Moral Education, London: George Allen \& Unwin.

Piaget, Jean, 1967. Six Psychological Studies, New York: Vintage Books.
Prasetya, L., dkk. (ed.), 2004. Menjadi Anak Beriman Yang Terbuka Untuk Sekolah Dasar Kelas I, Yogyakarta: Kanisius.

Ronald, D. dan M. Whelan, 1982. Perkembangan Moral Perkenalan dengan Piaget dan Kohlberg. Yogyakarta: Kanisius.

Supratiknya, A., (ed.), 1995. Teori Perkembangan Kepercayaan Karya-Karya Penting James W. Fowler. Yogyakarta: Kanisius.

Woolfolk, A., 2009. Educational Psychology Active Learning Edition, Yogyakarta: Pustaka Pelajar. 